\title{
Relike të hershme të monumenteve të fjalës në luginën e Shkumbinit
}

\author{
Skënder Karriqi
}

\begin{abstract}
Abstrakt
Teksa mediton mbi variante të tilla, ku brenda rrëfimit në prozë ka prani vargjesh, të cilat edhe ato bëhen objekt i rrëfimit për shkak të natyrës së veçantë të organizimit të fjalës, një mendje të thotë se sot ato s’janë gjë tjetër, veçse variantet e dekonstruktuara të varianteve historike në vargje. Ashtu siç ka ndodhur me monumentet e gurit: qytetet antike, kalatë, urat, etj., një pjesë e mirë e të cilave janë kthyer në rrënoja, veç nyjave strukturore të tyre: harqeve, kolonave, arkitrarëve etj., ashtu ka ndodhur edhe me këto monumente të fjalës përgjatë historisë, vargjet janë shpërbërë. Me sa duket, për arsye të ndryshme historike, mekanizmat e transmetimit nga brezi në brez nuk kanë mirëfunksionuar. Për pasojë monumentet e fjalës në vargje, kanë mbërritur te brezat pasardhës thjeshtë në statusin e një informacioni në prozë për një ngjarje, të cilën ata vazhduan ta rrëfejnë siç e morën; në prozë. Ashtu sikurse monumentet e gurit janë rezistente pikërisht në nyjet strukturore, edhe këto relike të monumenteve të hershme të fjalës janë rezistente në nyje të tilla; në pika kulmore të subjektit apo në kthesa të rëndësishme të tij. Pikërisht për këtë arsye këto nyje vazhdojnë të mbeten në vargje, për më tepër duke u shenjuar si një mënyrë e veçantë e rrëfimit të ngjarjes apo historisë në momente të rëndësishme të saj.
\end{abstract}

Peloni, qyteti antik i Selcës së Poshtme në krahinën e Mokrës, i zbuluar prej arkeologëve shqiptarë në fillim të viteve 70-të, dëshmon për një zhvillim normal qytetar, autokton të viseve ilire: duke qënë në brendësi të territorit shqiptar, pikërisht në një prej trevave si Mokrra, ku kultura shqiptare 


\section{Albanon}

\section{Revistë kulturore}

manifeston pastërtisht veçori etnike, ky qytet, si zbulim arkeologjik, dëshmon se qytetërimi ilir nuk është vepër e kolonëve, por një produkt origjinal i vendasve historikë, ilirëve, sigurisht, i lidhur me qytetërimet e tjera me të cilat jepte dhe merrte, që në shek IV-I p.e.s. Prof. Neritan Ceka në studimin me titull "Qyteti ilir pranë Selcës së Poshtme", ndër të tjera e përshkruan si më poshtë panoramën gjeografike të zonës ku ndodhet ky qytet: "... ai ishte vendbanimi më madh i krahinës së Mokrrës dhe gjatë Luginës së Skumbinit. Kjo krahinë që rrethohet nga amfiteatri gjigand i maleve të Polisit, Gjemthit, Kamjes, Jamës dhe Rrajcës, përbën një pellg gjeografik të përcaktuar qartë. Prej shpateve të tyre zbresin drejt shtratit të ngushtë të Shkumbinit, që e pret mëdysh pellgun, vargje kodrash të përshtatshme për zhvillimin e bujqësisë. Përvec ultësirës së Domosdovës nuk ka fushë tjetër".

Sigurisht, me këtë skicim gjeografik duhet të përkojë patjetër edhe rrezatimi qytetar i Pelonit antik. Lugina e Shkumbinit ishte lehtësisht më e përshtatshmja për dalje në perëndim drejt zonës bregdetare dhe si e tillë ajo duhet të ketë qënë edhe përçuesja më e hershme e shenjave kulturore ilire të qytetit. Për këtë dëshmitë janë të shumta, por siç është e natyrshme për arkeologjinë, ato dëshmi janë shenja të gurta rrënojash, gdhendjesh e derdhjesh numizmatike dhe si të tilla, flasin me gjuhën e tyre të gurtë. Ato që arkeologjia i ka vuajtur gjithmonë si mungesa, mbeten monumentet $\mathrm{e}$ fjalës, sidomos për periudhat e hershme të përtejshkrimit. Në të vërtetë vetë gjuha është monumenti më i vjetër, por në vazhdimësinë e saj, ajo përveç se në rastet e shkruara, nuk e ruan formën e vjetër të produkteve të saj poetike të ligjëruara historikisht. Përkundrazi, edhe pse shumë të vjetra: baladat, legjendat, këngët e dasmës, këngët erotike etj., vijnë nëpërmjet gjuhës së sotme, ose gjuhës së disa dekadave më parë. Shumë-shumë diferenca është ndërmjet së tashmes dhe kohës së regjistrimit të tyre. Gjithsesi reliket, shenjat e monumenteve të fjalës mbeten, sado të pakta qofshin ato, prandaj identifikimi i tyre në vargje, idioma, përralla, legjenda, etj., është një moment plotësimi, që ndonëse asnjëherë në mënyrë të plotë, kompenson shumëçka nga mungesa e pazëvendësueshme e këtyre monumenteve.

Pikërisht, këtë ndiesi të fortë plotësimi ke kur dëgjon vargjet e "Këngës së Diellit”, kënduar dikur, sipas dëshmisë së subjektit mbartës, nga vajzat dhe nuset e Luginës së Shkumbinit, që siç e thamë më lart, duhet të ketë qenë edhe përçuesja e rrezatimit kulturor të Pelonit antik. Vargjet e këngës janë si më poshtë: 
Diell o mor Diell-o,

A i pe syzezat-o?

I pashë si nuk i pashë,

Anës së malit kur rashë.

Këtu drejt kaluan-o,

Më vranë e më shuan-o,

Fustan hasebardhat-o.

Ika i zemëruar,

Me dritë të shuar.

Ajo që vihet re në variantet folklorike të Luginës së Shkumbinit dhe krahinave përreth saj ka të bëjë me natyrën e përzier të tyre. Varianti i "Këngës së Tanës" (Aishes) p.sh., rrëfehet si përrallë dhe në momentin e komunikimit me anë të fyellit, kalohet në vargjet e këngës së njohur të Tanës. E tillë është edhe përralla për Rostaninë, vajzës që në rrethana të caktuara, qe e detyruar të bashkëjetojë për një kohë të gjatë me ariun. Një ditë ajo fshehu në shpellën ku bashkëjetonte me bishën, vëllain e vet, i cili pas kërkimesh të gjata nëpër pyje, e kishte gjetur. Kur vjen ariu në shpellë, i thotë:

Rostani a biii...

Vjen era njeri...

Në këtë moment kritik për të, Rostania ia pret ariut:

Njeri qesh

E njeri jam,

Njeri tjetër,

Këtu s'kam...

Për t'u përmendur është edhe vajtimi i kecit në grykën e pusit, ku qe mbytur zonja e tij e dikurshme, nusja e re e mbretit, e shtyrë pabesisht nga shemra e saj, e cila nuk mund të sillte në jetë një trashëgimtar. Është fjala për përrallën "Nusja e mbretit dhe keci", që tregohet në malësinë e anës së majtë të lumit Shkumbin, në Stravaj, Farret, e deri në Polis e Sopot. Në një variant të 


\section{Albanon}

\section{Revistë kulturore}

përmbledhur, kjo përrallë gjendet edhe në antologjinë e Jeronim de Radës me titullin "Vashëza dhe Dhia" [1896]. Ja vajtimi i kecit pas shtjellimit në prozë të subjektit mbi fatin e vajzës së dëbuar nga njerka e saj:

Thikatë po prihen-o,

Kazanët po zien-o,

Për mua të mjerin -o,

Zonja ime zonjë...!

Pas këtyre vargjeve, nëpërmjet të cilave keci vendos kontaktin me botën e poshtme ku gjendet nusja e mbretit (në barkun e peshkut të madh dhe ka lindur një djalë me yll në ballë), subjekti vazhdon përsëri në prozë, deri te zgjidhja e lumtur.

Natyra e përzier e këtyre varianteve folklorike të Luginës së Shkumbinit dhe krahinave përreth, ashtu siç janë, në prozë dhe në vargje, (edhe pse ka pak të tilla), ndër të tjera është edhe një dëshmi metapoetike, pasi përveç situatave të ngjarjes dhe fatit të personazheve, objekt rrëfimi në këto përralla bëhen edhe vargjet, të cilat në të gjitha rastet përbëjnë pika kulminante apo momente kthesash të rëndësishme të subjektit, përtej të cilave vijnë zgjidhjet e lumtura. Në përrallën e Aishes, p.sh., vargjet e thëna me fyell përbëjnë kulmin, përtej të cilit vjen zgjidhja e tillë: çobanët e tjerë dhe fshatarët, pasi u njoftuan për grabitjen, sulmuan hajdutët dhe shpëtuan bagtinë bashkë me çobanin e marrë peng. Ndërsa në përrallën e Rostanisë komunikimi (dialogimi) në vargje i Rostanisë dhe ariut është momenti kulmor i tendosjes së subjektit, pas të cilit edhe këtu vjen zgjidhja më se e lumtur: vëllai e rrëmben motrën dhe, pasi i shpëton ndjekjes së ariut, e kthen Rostaninë në shtëpi. Po kështu ndodh edhe me përrallën "Nusja e re e mbretit dhe keci" ku vajtimi i këtij të fundit përsëri është moment kulmor komunikimi, përtej të cilit përsëri vjen zgjidhja e lumtur: shpëtimi i nuses së re të mbretit dhe djalit të saj të vogël, trashëgimtarit me yll në ballë, (nxjerrja e tyre nga barku i peshkut të madh).

"Kënga e Diellit", ndryshe nga variantet e mësipërme, nuk të lë përshtypjen e një varinti të dekonstruktuar, siç përshkruam ata më lart. Përkundrazi, ajo duket se është njësi e plotë poetike, çka provohet me faktin se ajo mund të qëndrojë e mëvehtësishme, e pavarur nga rrëfimi në prozë, sikurse janë vargjet në variantet më lart. Kur flitet për ndryshim në kohëra të kësaj kënge, ai ka të bëjë veçse me sublimimin e saj duke u çliruar nga elemente e 
detaje që e mbanin të lidhur pas kohërave e hapësirave të caktuara. Kështu, e sublimuar, ajo vjen deri në ditët tona me statusin e një universaleje të lirë nga detaje historike dhe të thjeshtuar maksimalisht në detajet subjektore. Kjo është mënyra se si ajo është përshtatur dhe integruar përgjatë historisë. Nga ana tjetër , edhe pse "çlirimi" ndodh, shpejt apo vonë sidoqoftë, shenjat e "robërisë" së dikurshme mbeten, ashtu të sublimuara, edhe pse nuk e kanë aftësinë të të diktojnë apo të të komunikojnë përmbajtje historike (pikërisht për shkak të sublimimit). Pavarësisht nga kjo, ato të ashtuquajturat shenja të sublimuara, të sygjerojnë.

Martin Bernal, duke dashur të argumentojë tezën e prejardhjes së qytetërimit antik grek, në librin "Athina e Zezë", evokon në një këndvështrim krejt tjetër, mitin e Danait dhe 50 bijave të tij danaide. Sipas tij, ky mit është një ndër shenjat e sigurta të kolonizimit të Greqisë antike prej egjiptianëve. Po sipas tij, ishte elita kulturore greke e kohës antike, sidomos ajo e shek V p.e.s., që iu kundërvu këtij miti, me qëllim që në pamundësi për ta mohuar të vërtetën e tij rreth kolonizimit egjiptian me të cilin lidhet prejardhja e qytetërimit antik grek, të paktën për ta modifikuar atë dhe për ta përcjellë si të tillë në horizontin kulturor të së ardhmes. Ndër më aktivët e elitës greke në këtë aksion ishte Eskili, që, sipas Bernal-it: "...ishte i mbushur me atë ndjenjë, $e$ cila me mjaft përfitim mund të quhet nacionalizëm helenistik dhe se ndërkohë kërkonte ta zvogëlonte ndikimin e çdo pushtimi ... Drama e tij "Persët," shprehte drejtpërdrejt pasionet ksenofobike të brezit të tij. Te "Lutëset" ato vetëm se janë të maskuara në mënyrë fine".

Në fakt, pasi ke lexuar "Lutëset", të vetmen pjesë të mbetur nga triologjia e Eskilit mbi mitin e Danait, në mendje të mbetet fabula e 50 djemve të Egjiptit në ndjekjen e 50 vajzave, kushërirave të tyre me të cilat donin të martoheshin. Më tej fabula detajohet në episode të pritjes së 50 vajzave në Argos dhe vendimi popullor demokratik për t'i pranuar ato dhe babain e tyre shoqërues të jetojnë aty, në Argos. Me sa duket, kjo është mënyra se si Eskili, në pozita aktive të nacionalizmit helenistik, e modifikon mitin e Danait dhe vajzave të tij, duke e shtjelluar atë thjesht si një raport të disa lutëseve të ardhura prej vendeve barbare, shoqëruar nga ati i tyre fatkeq, me demokracinë antike greke. 


\section{Albanon}

\section{Revistë kulturore}

Në “Këngën e Diellit” është mbresëlënës pikërisht imazhi i djemve që janë në ndjekje apo në kërkim të vajzave. Hipotetikisht mund të mendohet se kjo këngë është një invariante e mitit të Danait dhe pesëdhjetë vajzave të tij, të ndjekura nga pesëdhjetë kushërinjtë e tyre. Për shkak të sublimimit, ky invariant vjen deri në ditët tona si një idil dashurie. Të lodhur në aventurën e tyre, madje shpresëhumbur, djemtë i kërkojnë ndihmë Diellit, kryeperëndisë së ilirëve, se të tillë ishin ata, ilirë. Në fakt, ky moment sublim komunikimi, në planin diakronik duhet të përkojë me një ceremonial lutjesh apo edhe flijimesh në faltoren e Diellit. Që kjo këngë mund të ketë qenë një njësi e plotë epike, për këtë të bën të mendosh karakteri dialogjik i saj, i cili mishërohet në dy vargjet e para përkundrejt përgjigjes së Diellit në shtatë vargjet e tjera:

$$
\begin{aligned}
& \text { Diell o mor Diell - o, } \\
& \text { A i pe syzezat - o? }
\end{aligned}
$$

I pashë si nuk i pashë

Në një legjendë mbi origjinën e këngës polifonike, Dielli del në shenjën e perëndisë më të fuqishme, që me fyellin e tij magjik thërret në kuvend, në malin e shenjtë të Tomorrit, perëndinë e Detit, të Malit, të Lumit, të Pyjeve, të Hënës dhe të Yjeve, ku do të vendosnin krijimin e këngës polifonike. Me sa shihet, në këtë këngë perëndia e Diellit është në funksionin e Muzës, ndaj djemtë i drejtohen atij, ashtu si Homeri i drejtohej Muzës t’i tregonte për zemërimin e Akilit, që aq shumë kobe akejve u solli. Doemos që grupi i papërcaktuar i djemve në këtë këngë përkon me korin (e djemve) i prirë nga korifeu, i cili për shkak të cilësive të veçanta, komunikon me Diellin. Duke u shkruar në shek VII p.e.s., në kohën e Pisistratit, eposi grek në një farë mënyre ngriu, ndali së sublimuari, për të mbërritur deri në ditët tona i rëndë, me shumë materie historike dhe fizike: me armë, kufoma, dylyftime, robinja, dredhi, tradhëti etj. Ndërsa kjo këngë, ndoshta dikur një njësi e plotë epike, vjen sot e çliruar nga pesha materiale: ajo është e butë, e lehtë, pasi të gjitha imazhet që sygjeron, vendosen në hapësirën e ndritshme ndërmjet Diellit dhe pyjeve ku djemtë, në aventurën e tyre kërkojnë vajzat. Eshtë grupi përcaktor "...fustan hasebardhat-o" shenja etnografike e autoktonisë së "Këngës së Diellit”. Në veshjet popullore të fshatrave të Domosdovës dhe në të dyja anët e luginës së Shkumbinit, deri në malësi mbisundon e bardha 
(fustanet dhe këmishat e bardha). Pikërisht ky imazh virtual i vajzave dhe nuseve të luginës na vjen prej shekujsh nëpërmjet "Këngës së Diellit". Si shtatoret e bardha të një qyteti antik, të çliruara nga pesha e mermerit apo granitit, e baltës dhe e errësirës, ato vajzat dhe nuset e bukura të luginës së Skumbinit kanë zënë vend: të lehta, të bukura, diellvrasëse, aty në vargjet e "Këngës së Diellit", këtë relike të hershme të monumeteve të fjalës në këto treva të lashta ilire. 